\title{
Simultaneous supratentorial and brainstem abscesses due to Listeria monocytogenes ${ }^{\text {th }}$
}

\section{Abcès à listeria monocytogènes : atteinte simultanée supratentorielle et du tronc cérébral}

\author{
J.P. Soares-Fernandes ${ }^{a, *}$, P. Beleza ${ }^{b}$, J.J. Cerqueira ${ }^{b}$, M. Ribeiro ${ }^{a}$, R. Maré ${ }^{b}$, \\ E. Lourenço ${ }^{b}$, J.F. Rocha ${ }^{a}$
}

a Department of Neuroradiology, Hospital de S.-Marcos, Braga, Portugal

${ }^{b}$ Department of Neurology (PB, J-JC, RM, EL), Hospital de S.-Marcos, Braga, Portugal

Available online 29 August 2007

\section{KEYWORDS}

Brain abscess;

Listeria

monocytogenes;

Magnetic resonance

imaging

\section{MOTS CLÉS}

Listeria

monocytogenes ;

Tronc cérébral ;

Abcès ;

Imagerie par

résonance

magnétique

\begin{abstract}
Multiple supratentorial abscesses caused by Listeria monocytogenes are rare. We report the simultaneous occurrence of multiple supratentorial and brainstem abscesses due to Listeria, in a patient under corticotherapy for an exacerbation of ulcerative colitis. MR imaging features before and after successful conservative treatments are depicted. In immunocompromised patients with supratentorial listerial abscesses, the coexistence of brainstem abscedation is exceptional. Despite high mortality associated with listerial abscesses, this case illustrates the possibility of a good clinical outcome, if the appropriate antibiotic regimen is instituted and the immunosuppressant agent is discontinued.
\end{abstract}

(c) 2007 Elsevier Masson SAS. All rights reserved.

Résumé Les abcès multiples supratentoriels à Listeria monocytogenes sont rares. Nous rapportons l'observation de la survenue simultanée d'abcès multiples supratentoriels et du tronc cérébral chez un patient sous corticothérapie pour colite. Les aspects en imagerie par résonance magnétique (IRM), avant et après un traitement sont décrits. Chez les patients présentant un déficit immunitaire, une atteinte listérienne supratentorielle coexistant avec des abcès du tronc cérébral est exceptionnelle. Cette observation illustre la possibilité d'une évolution clinique favorable, si le traitement antibiotique est institué et le traitement immunosupresseur arrêté. (c) 2007 Elsevier Masson SAS. All rights reserved.

\footnotetext{
Disclosure: the authors have reported no conflicts of interest.

* Corresponding author.

E-mail address: jsf@bragatel.pt (J.P. Soares-Fernandes).
} 


\section{Introduction}

Listeria monocytogenes is an intracellular Gram-positive rod that is known to cause systemic and central nervous system (CNS) infection, afflicting mainly the immunossuppressed and perinatal-neonatal populations [12].

CNS involvement by $L$. monocytogenes includes meningitis and other less common manifestations, such as meningoencephalitis, rhomboencephaplitis, cerebritis and abscesses [2,9,14]. Brain abscesses account for approximately $10 \%$ of CNS listerial infections and are seen in $1 \%$ of all listerial infections [10].

In 2003, Cone et al. [6] reviewed published cases of brain abscesses due to $L$. monocytogenes. Thirty of the 40 observed were solitary ones and only four presented with more than three abscesses.

We present a case of multiple Listeria brain abscesses, describe its imaging findings and discuss the potential physiopathologic mechanism of this infection.

\section{Case report}

A 46-year-old woman presented to our emergency department with a five-day history of general malaise, fever, headaches and progressive lethargy. She took prednisolone (40 mg per day) for an exacerbation of her ulcerative colitis 6 weeks before and had recently been diagnosed to have diabetes mellitus.

On examination, the patient was feverish $\left(40.4{ }^{\circ} \mathrm{C}\right)$, comatose, with conjugate eye deviation to the right. She also exhibited left hemiparesis and evident neck stiffness.

Laboratory analysis showed a mild leukocytosis $\left(13.1 \times 10^{9} / \mathrm{l}\right)$ and elevated C-reactive protein $(75 \mathrm{mg} / \mathrm{l})$. A lumbar puncture revealed an opening pressure of $490 \mathrm{~mm}$ of water, a leukocyte count of 50 cells $/ \mathrm{mm}^{3}$ (consisting of
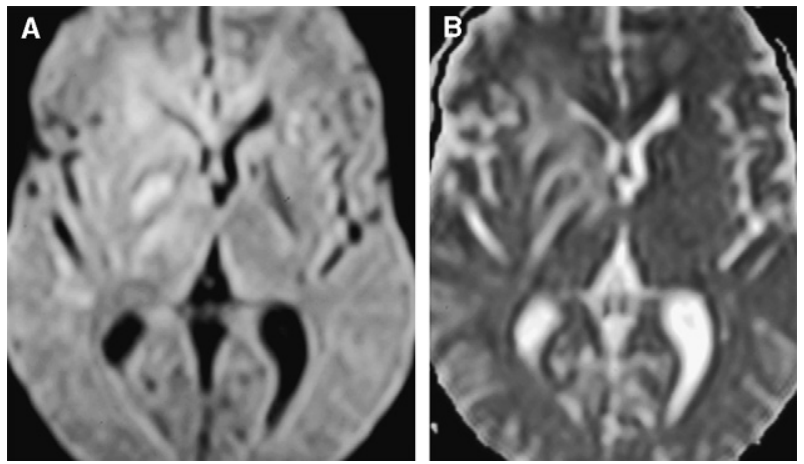

Figure $2 \mathrm{~A}$, DWI, and $\mathrm{B}, \mathrm{ADC}$ images demonstrate restricted diffusion in the lenticular nucleus.

Figure 2 L'image pondérée en diffusion (A) et la cartographie $A D C(B)$ montrent une restriction de la diffusion au niveau du noyau lenticulaire droit.

$67 \%$ neutrophils), a glucose level of $42 \mathrm{mg} / \mathrm{dl}$ (serum level of $168 \mathrm{mg} / \mathrm{dl}$ ) and a protein level of $1.14 \mathrm{~g} / \mathrm{l}$.

MR imaging displayed multiple rounded lesions, with variable sizes, involving the right thalamus, basal ganglia and frontal white matter. The midbrain structures were bilaterally involved. The lesions were characterized by prolonged T2 (Fig. 1A), restricted water diffusion (Fig. 2) and ringlike or nodular enhancement after contrast administration (Fig. 1B-D).

Cultures of blood and CSF samples yielded L. monocytogenes. An ultrasound study of the abdomen failed to reveal hepatic lesions. The patient was treated with intravenous ampicillin ( $8 \mathrm{~g}$ per day) for eight weeks and gentamicin (300 mg per day) for 4 weeks. She recovered her consciousness within five weeks and was discharged with slight bilateral restriction of ocular abduction and
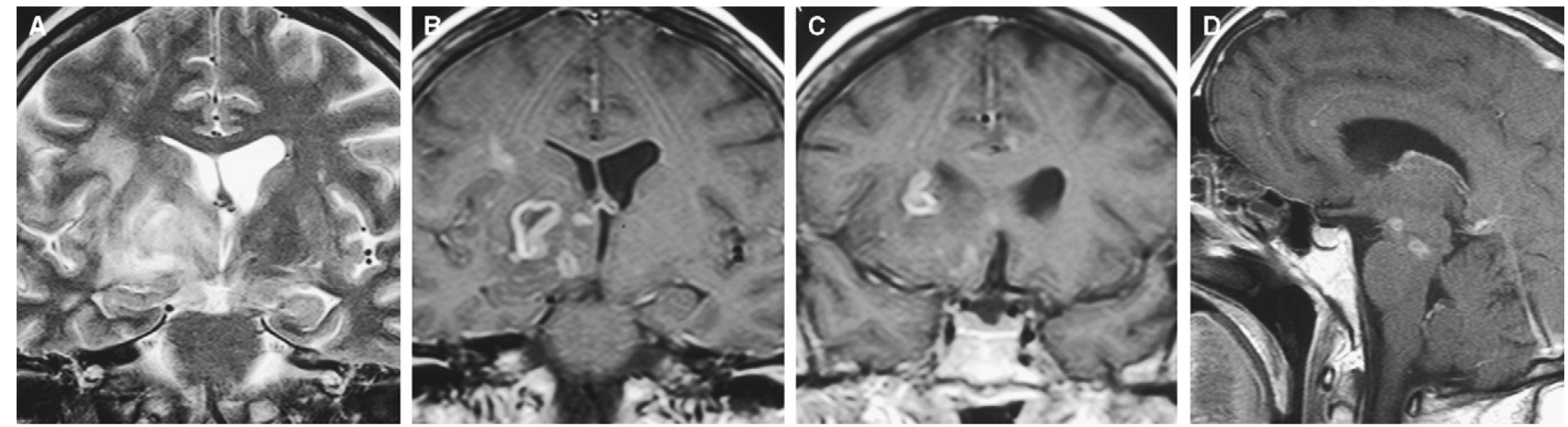

Figure 1 A, coronal T2-weighted image demonstrates pathological high signal in the right thalamus, lenticular nucleus and frontal subcortical white matter. The right frontal horn and the third ventricle are deformed due to lesional mass effect. No hypo-intense rim is seen. B, C and D, post-gadolinium injection, T1-weighted MR imaging; B and C (coronal images) show supratentorial ringenhancing lesions in the right thalamus, lenticular nucleus, head of caudate and frontal subcortical white matter. Note smaller lesions exhibiting nodular enhancement, in the same locations; D (sagital image) reveals abscess-like lesions in cerebral peduncle and transition between pons and midbrain.

Figure 1 L'image pondérée T2 dans le plan coronal montre un hypersignal intéressant le thalamus, le noyau lenticulaire et la substance blanche sous-corticale frontale du côté droit. Il existe un effet de masse sur la corne fontale droite et le troisième ventricule. $B, C$ et $D$ : séquence $T 1$ après injection de gadolinium. Les images coronales $(B$ et $C$ ) montrent des lésions supratentorielles rehaussées en périphérie au niveau du thalamus, du noyau lenticulaire, de la tête du noyau caudé et de la substance blanche souscorticale frontale du côté droit. À noter un rehaussement nodulaire des petites lésions dans les mêmes localisations. L'image sagittale $(D)$ révèle des lésions abcédées au niveau des pédoncules cérébraux et de la jonction pont et pédoncules cérébraux. 
moderate left-sided hemiparesis (grade 4/5). She could walk with unilateral support. Outpatient physiotherapy was arranged.

MR images obtained before discharge showed nearly complete resolution of lesions, with residual enhancement in the right basal ganglia, after contrast administration. At that time, CSF white blood cell count was of 6 cells $/ \mathrm{mm}^{3}$; glucose and protein levels were normal. No bacteria were cultured.

\section{Discussion}

L. monocytogenes is believed to reach the CNS by haematogenous spread from the gastrointestinal tract. Ingestion of Listeria-contaminated food is considered to be the source of virtually all human infections [6]. Once ingested, it penetrates into Peyer's patches of the small intestine gaining access to the mesenteric lymph nodes and then to the blood. In our patient, intestinal lesions of ulcerative colitis may have facilitated invasion. Previously, listerial disease has also been associated to perforating duodenal ulcer, caecal gangrene, Crohn's disease, carcinoma of the rectum and shigellosis [15].

Once in the bloodstream, Listeria travels mainly in nonlistericidal macrophages spreading from cell to cell without contact with the extracellular space [7].

In the CNS, meningitis may follow as the organism attaches to the epithelial cells on the choroid plexuses. Cerebritis and subsequent abscess formation result from penetration in the brain parenchyma, through the cerebral capillary endothelium, via middle cerebral artery. Therefore, bacteraemia is a laboratory finding in about $86 \%$ of Listeria abscesses. Bacteraemia is an unusual laboratory finding in brain abscesses caused by other bacteria, occurring in $11 \%$ of cases [8]. As in our case, listerial brain abscess have been associated with meningitis in up to $38 \%$ of the patients [8].

On the other hand, listerial rhombencephalitis may be explained by axonal transport of food borne Listeria to the brainstem, after entering cranial nerve endings [1]. The proposition of two different mechanisms for two different lesions (supratentorial abscesses and rhombencephalitis) strengthens the presumed blood dissemination through the perforating arteries of the basal ganglia and brainstem in our patient.

The limited number of reported cases of multiple brain abscesses caused by $L$. monocytogenes provided few reports of MR imaging correlations. Involvement of the subcortical grey matter, such as the thalamus and the basal ganglia, are more common than in abscesses due to other agents, occurring in up to $21 \%[8,10]$. The frontoparietal subcortical white matter is another elective location.

Seventy-five percent of patients presenting more than one listerial supratentorial brain abscess are immunosuppressed versus $58 \%$ of those with solitary abscesses, suggesting that suppressed immunity is a risk factor for listerial brain abscesses and even more so with multiple ones [6]. Differently, rhombencephalitis often occurs in otherwise healthy adults, with only $8 \%$ of cases found in immunosuppressed patients [2].
Since listerial abscesses are rare entities, alternative diagnosis of more common conditions occurring in the immunocompromised patient must be considered. Toxoplasmosis also presents with multiple lesions, involving the basal ganglia. However, normal ADC values are usually seen [5]. Pyogenic abscesses are infrequently multiple and typically show restricted diffusion [4]. Additionally, a rim of hyperintensity on T1-weighted images and low signal on long-TR sequences due to the presence of free radicals is characteristically found. In our case, basal ganglia abscesses showed restricted diffusion, without a rim of free radicals.

The combination of ampicillin (for a minimum of 4 weeks) and gentamicin (for 2-4 weeks) is the regimen of choice for the treatment of listerial brain abscess $[11,13]$. Trimethoprim-sulphametoxazole may be a reasonable alternative for the treatment of patients with allergy to penicillin.

Mortality is high and not significantly different in patients with more than one abscess (44\%) from those with a single abscess (40\%) [6]. However, it is significantly higher than in non-listerial supratentorial brain abscess.

Finally, we excluded the concomitant presence of hepatic abscesses, which seems to predict a dismal outcome. In Braun's review of liver abscesses due to $L$. monocytogenes [3], all the patients with multiple liver abscesses expired, while those with solitary ones survived.

Despite high mortality associated with listerial abscesses, this case illustrates the possibility of a good clinical outcome, if the appropriate antibiotic regimen is instituted and the immunosuppressant agent is discontinued.

\section{References}

[1] Antal EA, Loberg EM, Dietrichs E, Maehlen J. Neuropathological findings in 9 cases of Listeria monocytogenes brain stem encephalitis. Brain Pathol 2005;15(3):187-91.

[2] Armstrong RW, Fung PC. Brainstem encephalitis (romboencephalitis) due to Listeria monocytogenes: case report and review. Clin Infect Dis 1993;16:689-702.

[3] Braun TI, Travis D, Dee RR, Nieman RE. Liver abscess due to Listeria monocytogenes: case report and review. Clin Infect Dis 1993;17:267-9.

[4] Chang SC, Lai PH, Chen WL, Weng HH, Ho JT, Wang JS, et al. Diffusion-weighted MRI features of brain abscess and cystic or necrotic brain tumors: comparison with conventional MRI. Clin Imaging 2002;26(4):227-36.

[5] Chong-Han CH, Cortez SC, Tung GA. Diffusion-weighted MR imaging of cerebral toxoplasma abscess. Am J Roentgenol 2003;181:1711-4.

[6] Cone LA, Leung MM, Byrd RG, Annunziata GM, Lamm RY, Herman BK. Multiple cerebral abscesses because of Listeria monocytogenes: three case reports and a literature review of supratentorial listerial brain abscess(es). Surg Neurol 2003;59:320-8.

[7] Drevets DA, Canono BP, Campbell PA. Listericidal and nonlistericidal mouse macrophages differ in complement receptor type 3-mediated phagocytosis of $L$. monocytogenes and in preventing escape of the bacteria into the cytoplasm. J Leukoc Biol 1992;52:70-9.

[8] Eckburg PB, Montoya JG, Vosti KL. Brain abscess due to Listeria monocytogenes: five cases and a review of the literature. Medicine (Baltimore) 2001;80:223-35.

[9] Kaplan MM. Listeriosis. N Engl J Med 1945;232:755-9. 
[10] Lorber B. Listeriosis. Clin Infect Dis 1997;25:763-81.

[11] Michelet C, Leib SL, Bentue-Ferrer D, Tauber MG. Comparative efficacies of antibiotics in a rat model of meningoencephalitis due to Listeria monocytogenes. Antimicrob Agents Chemother 1999;43:1651-6.

[12] Milonakis E, Hohmann EL, Calderwood SB. Central nervous system infection with Listeria monocytogenes: 33 years' experience at a general hospital and review of 776 episodes from the literature. Medicine 1998;77:313-24.
[13] Moellering Jr RC, Medoff G, Leech I, Wennersten C, Kunz LJ. Antibiotic synergism against Listeria monocytogenes. Antimicrob Agents Chemother 1972;1(1):30-4.

[14] Nieman RE, Lorber B. Listeriosis in adults: a changing pattern: report of eight cases and review of the literature, 1968-1978. Rev Infect Dis 1980;2:207-27.

[15] Sjostrom A, Olsson T, Burman LA, Tarnvik A. Listerial brain abscess in an immunocompetent adult with a predisposing intestinal condition. J Infect 1995;30:185-6. 